Research Report No. 34/2009

\title{
Born to Be Wild: The 'Trans-Systemic' Programme at McGill and the De-Nationalization of Legal Education
}

Helge Dedek

Armand de Mestral

Follow this and additional works at: http://digitalcommons.osgoode.yorku.ca/clpe

\section{Recommended Citation}

Dedek, Helge and de Mestral, Armand, "Born to Be Wild: The 'Trans-Systemic' Programme at McGill and the De-Nationalization of Legal Education" (2009). Comparative Research in Law \& Political Economy. Research Paper No. 34/2009.

http://digitalcommons.osgoode.yorku.ca/clpe/146 


\section{Comparative Research in Law \& Political Economy}

CLPE RESEARCH PAPER 34/2009

Helge Dedek and Armand de Mestral

Born to be Wild: The "Trans-Systemic" Programme at McGill and the De-Nationalization of Legal Education

EDITORS: Peer Zumbansen (Osgoode Hall Law School, Toronto, Director, Comparative Research in Law and Political Economy, York University), John W. Cioffi (University of California at Riverside), Nassim Nasser (Osgoode Hall Law School, Toronto, Production Editor)

Also available at: http://www.germanlawjournal.com 



\section{German Law Journal}

Born to be Wild: The "Trans-Systemic" Programme at McGill and the De-Nationalization of Legal Education

Helge Dedek and Armand de Mestral

10 German Law Journal 889 (2009), available at:

http://www.germanlawjournal.com/article.php?id=1128

This article was originally published in Volume 10, Number 7 of the German Law Journal as part of the journal's $10^{\text {th }}$ anniversary symposium on "Transnationalizing Legal Education" edited by Nadia Chiesa, Adam de Luca, and Bernadette Maheandiran. 
CLPE Research Paper 34/2009

Vol. 05 No. 06(2009)

\title{
Helge Dedek and Armand de Mestral
}

\section{Born to be Wild: The “Trans-Systemic" Programme at McGill and the De-Nationalization OF LEgal EdUCATION}

\begin{abstract}
One of the major challenges legal education faces nowadays is that jurisdictional boundaries are losing significance in an internationalized, globalized and post-regulatory environment. This calls into question the very notion of "law" itself, at least as traditionally understood as a system of posited norms within a given jurisdiction, and the classic model of legal education based on such an understanding of law. While North American legal education has a longstanding tradition of self-reflection, the situation in Europe is different: there is little incentive for legal scholars to devote a considerable amount of time to a serious scholarly treatment of the issue of legal education. Whereas the challenge of internationalization, particularly in its emanation of "Europeanization", has literally become omnipresent in legal discourse, legal education is still dominated by a traditionalist view of its primary goal: an almost exclusive focus on training lawyers (or judges) for the practice within the boundaries of a national jurisdiction. As a contribution to the debate on the challenges posed to the teaching of law we would like to offer the following brief analysis of the efforts made at the Faculty of Law of McGill University, situated in Québec, Canada to develop a new approach to the teaching of law. Ten years ago, in 1998, the Faculty undertook the effort to offer an integrated comparative three year curriculum, known as the McGill Programme, that teaches even first year introductory courses, such as Contracts and Torts, from a comparative perspective. The ultimate aspiration of this programme, however, is to transcend the fixation on the study of law as the study of "legal systems" - hence the label "trans-systemic" legal education.
\end{abstract}

Keywords: Legal education, Legal education at McGill University, Trans-systemic

JEL classification: K10, K40

Helge Dedek

Assistant Professor of Law, McGill University. helge.dedek@mcgill.ca

Armand de Mestral

Professor of Law, McGill University,

Jean Monnet Professor, formerly Co-director of the Institute for European Studies, Université de Montréal - McGill University, Email: armand.de.mestral@mcgill.ca 



\title{
SPECIAL ISSUE: TRANSNATIONALIZING LEGAL EDUCATION
}

\section{Born to be Wild: The "Trans-systemic" Programme at McGill and the De-Nationalization of Legal Education}

\author{
By Helge Dedek \& Armand de Mestral*
}

\section{A. Introduction}

Legal education is changing. What is changing is our understanding of "education", of how we learn and how we should teach. ${ }^{1}$ Also changing is our understanding of how to define what is "legal" about "legal education". Most will nowadays agree that legal education should be more than a vocational training for the practice of the profession in a particular jurisdiction. In analyzing the development of legal education in recent years, we can distinguish two trajectories. Firstly, there is the ongoing attempt of specifically the North American legal academy to make legal studies a transdisciplinary endeavour, a development closely connected to the major "paradigm shifts" in legal theory in the $20^{\text {th }}$ century. ${ }^{2}$ Secondly, it seems that jurisdictional boundaries have lost significance in an internationalized, globalized and post-regulatory environment. ${ }^{3}$ This calls into question the very notion of "law" itself, at least as traditionally understood as a system of posited norms within a given jurisdiction. How should both developments be reconciled?

\footnotetext{
*Assistant Professor of Law, McGill University, helge.dedek@mcgill.ca; Professor of Law, McGill University, Jean Monnet Professor, formerly Co-director of the Institute for European Studies, Université de Montréal - McGill University, armand.de.mestral@mcgill.ca. The paper reflects and partly reiterates views previously expressed by the authors, cf. Armand de Mestral, Bisystemic Law Teaching - The McGill Programme and the Concept of Law in the EU, 40 Common Market Law Review (C.M.L. Rev.) 799 (2003); Helge Dedek, Recht an der Universität: "Wissenschaftlichkeit" der Juristenausbildung in Nordamerika, 64 Juristenzeitung 540 (2009). The authors thank Jean-Guy Belley, Barbara Dauner-Lieb, H. Patrick Glenn, Nicholas Kasirer, Lionel Smith and Peer Zumbansen for their helpful comments, and Avidan Kent for his editing assistance in the preparation of the manuscript.

${ }^{1}$ See, e.g., Martha Cleveland-Innes \& Claudia Emes, Principles of Learner-centered curriculum: Responding to the Call of Change, 35 THe CANAdian JOURnal OF Higher Education, 85-110 (2005).

${ }^{2}$ See, e.g., Paul Maharg, Transforming Legal Education, Learning and Teaching the law in the Early Twenty-first CENTURY, 77-98 (2007).

${ }^{3}$ See, for an introduction, Peer Zumbansen, Transnational Law, in ENCYCLOPEDIA OF COMPARATIVE LAW, 738 (Jan Smits ed., 2006).
} 


\section{USA: Challenging disciplinary rather than jurisdictional boundaries}

North American legal education has a longstanding tradition of self-reflection. The situation here is different from that in Europe, where there is little incentive for legal scholars to devote a considerable amount of time to a serious scholarly treatment of the issue of legal education. In North America, particularly in the USA, well-established institutions such as the "Journal of Legal Education", first published in 1948, stand witness to a lively discourse that is willing to engage in a discussion of curricular questions, methods used in the classroom, and, more broadly, the purpose of legal education as a whole. ${ }^{4}$ This discussion is connected to the debate about the "paradigm" of legal scholarship: ${ }^{5}$ what does it even mean, at this day and age, to talk about "legal" scholarship after the iconoclastic thrust of the realists, and the demise of "formalistic" doctrinal scholarship? What is the place of legal scholarship in the intellectual landscape of the university? ${ }^{6}$ For the "discipline" of law, which has traditionally defined itself as a "science" in its own right, these are truly existential questions. Many have answered the challenge by adopting interdisciplinarity as the new paradigm of legal scholarship (a paradigm which is, however, hard to define). ${ }^{7}$ This new paradigm also figures prominently in the way that law is now being taught: besides many courses focusing not only on "law", but on "law and...," even first year courses on "lawyer's law" such as Contracts or Torts include and embrace interdisciplinary perspectives on law, whether economic, historical, critical or otherwise.

Despite the courage displayed in facing such disconcerting and uncomfortable selfreflection, and despite the dedication to pedagogical progress, legal education in the USA has, however, traditionally been influenced by the fact that the USA is a whole continent and to a certain extent: a whole world - in itself: the prospect of looking at developments outside the USA might seem less tempting for Americans (one might add: especially for certain Supreme Court judges), than for scholars and lawyers in smaller or less powerful countries. The theoretical abstraction brought about by law schools' re-definition as "outpost of the graduate school" ${ }^{8}$ has not instigated a comprehensive process of re-

\footnotetext{
${ }^{4}$ See, e.g, Charles R. Lawrence III, The Word and the River: Pedagogy as Scholarship as Struggle, 65 SOUTHERN CALIFORNIA LAW REVIEW, 2231-2298 (1991-1992), on the interplay between scholarship and teaching from the perspective of a critical race scholar.

${ }^{5}$ Robert MacCrate, Paradigm Lost - or Revised or Regained?, 38 Journal of LeGAL EducAtion (J. LeGAL Educ.), 295 (1988); George L. Priest, Social Science Theory and Legal Education: The Law School as University, 33 J. LEGAL Educ, 437 (1983).

${ }^{6}$ Priest (note 5) See also Thomas S. Ulen, A Nobel Prize in Legal Science? Theory, Empirical Work and the Scientific Method in the Study of Law, 2002 UNIVERSITY OF ILLINOIS LAW REVIEW, 875, 916 (2002).

7 Charles W. Collier, Interdisciplinary Legal Scholarship in Search of a Paradigm, 42 DUKE LAW JournaL, (DuKE L. J.) 840, 842 (1992-1993).

${ }^{8}$ Paul Carrington, Butterfly Effects: The Possibilities of Law Teaching in a Democracy, 41 DUKE L. J, 741, 789 (1992).
} 
thinking jurisdictional boundaries. What remained "legal" in American legal education has so far primarily focused on American law.

Comparative law scholarship, for example, has a prominent tradition in the US, which is particularly closely linked to the names of the generation of Jewish-German émigré scholars fleeing from persecution. However, the role played by this "classical" comparative law in particular (and of other subjects that transcend national boundaries in general) in the curriculum of the American law school has been relatively insignificant. In 1998, Mathias Reimann noted that "in the United States today, comparative law does not play nearly as prominent a role in teaching, scholarship, and practice as one would expect in our allegedly cosmopolitan age. Perhaps the discipline is not in an outright crisis but it surely does not occupy a prominent place in the American legal universe either." ${ }^{\prime \prime}$ However, he also observed that "[i]t is quite common to blame the parochial attitude and lack of international sophistication of American lawyers for the marginal role of comparative law. But, as a matter of fact, interest in international legal subjects, ranging from human rights to foreign trade law and international litigation, is currently high and growing fast." American pedagogical discourse has begun to acknowledge the extent of the challenge posed by globalization, and has started to reflect on the question: how should students be prepared for "transnational challenges" ?"

\section{EU: "Europeanization" of Legal Education?}

In the EU member states, the situation is to some extent similar; there major are differences, however, in the weight of the driving factors. While the challenge of internationalization, particularly in its emanation of "Europeanization", has literally become omnipresent in legal discourse, legal education is still dominated by a traditionalist view of its primary goal: an almost exclusive focus on training lawyers (or judges) for the practice within the boundaries of a national jurisdiction.

\section{Europeanization and Traditional Positivism}

The internationalization and "Europeanization" of law has been a phenomenon that legal academia simply could not afford to ignore, and that was quickly recognized as a cornucopia of scholarly opportunity: while some found their calling in defending the

\footnotetext{
${ }^{9}$ Mathias Reimann, Stepping out of the European Shadow: Why Comparative Law in the United States Must Develop Its Own Agenda, 46 American Journal of Comparative LAW, (AM. J. COMP. L.) 637 (1998). See also William Twining, A Cosmopolitan Discipline? Some Implications of 'Globalisation' for Legal Education, 8 JOURNAL OF Commonwealth LaW and Legal Education, (J. Commonwealth L. \& Legal Educ.) 13, 25 (2001): “America might have been more inward-looking, but which legal culture has developed more sophistication in dealing with multiple jurisdictions and multi-culturalism?"

${ }^{10}$ See, for example, Louis Del Duca, Introduction to Educating Lawyers for Transnational Challenges, 23 PENN STATE International LaW ReVIeW, (Penn St. INT'L L. ReV.) 741 (2004-2005).
} 
technical and cultural achievements of their respective national legal orders, numerous scholars embraced "Europeanization" and embarked on projects that studied or even actively propelled the rapprochement and harmonization of national laws in the EC. ${ }^{11}$ The most recent example of the latter tendency is the draft of the Common Frame of Reference, the joint effort of a great number of private law scholars to develop a body of principles and rules of a European contract law. ${ }^{12}$

However, the influence of this development on legal education has been less noticeable than one might expect. A general shift to a truly "Europeanized" learning environment has so far not been effected. Until very recently, the debate on the "Europeanization" of law or even the actual "harmonization" of the legal orders of the member states had not had a didactic counterpart as to how to teach law in the face of Europe growing together. ${ }^{13}$

The discourse around the harmonization of law - particularly of private law - in the EU frequently invokes the historical "ius commune", the Continental "common law" based on "received" Roman law, as the lodestar of a new legal unity. ${ }^{14}$ It would be a mistake, however, to perceive the actual historical "ius commune" as a "uniform" system of legal norms that was "in force" on the continent, irrespective of regional traditions and local customs. ${ }^{15}$ On the contrary, the "ius commune" was rather an idea, a legal "lingua franca"

\footnotetext{
${ }^{11}$ See, e.g., TOWARDS A EUROPEAN CIVIL CODE $3^{\text {RD ED }} 353$ (Arthur Hartkamp \& Martijn W. Hesselink et. al. eds., 2004); jan Smits, The Making of European Private Law, Towards a lus Commune Europaeum as a Mixed Legal System (2002).

12 Principles, Definitions and Model Rules of European Private law, Draft Common frame of Reference, interim OUTLINE Edition (Christian von Bar, Eric Clive \& Hans Schulte-Nölke eds.,, 2008). For a recent critical assessment, see, e.g., Horst Eidenmüller, Florian Faust, Hans Christoph Grigoleit, Nils Jansen, Gerhard Wagner, and Reinhard Zimmermann, The Common Frame of Reference for European Private Law-Policy Choices and Codification Problems, 28 OXFORD JOURNAL OF LEGAL STUDIES, 659 (2008). Cf., on the politics of European private/contract law harmonization, the "Action Plan" of the Commission: Communication from the Commission to the European Parliament and the Council, A More Coherent European Contract Law, An Action Plan, COM (2003) 68 final, 12 February 2003. See also, e.g., Hugh Beale, The Future of the Common Frame of Reference, 3 EUROPEAN REVIEW OF Contract Law (E.R.C.L.) 257 (2007); Pierre Legrand, Antivonbar, 1 Journal of Comparative Law, 13 (2006); Hugh Collins et al., Social Justice in European Contract Law: a Manifesto, 10 EUROPEAN LAW JOURNAL, (EUR. L. J.), 653 (2004); Martijn.W. Hesselink, The Politics of a European Civil Code, 10 EUR. L. J., 675 (2004).

${ }^{13}$ Pierre Larouche, Recueils Jus Commune pour le Droit Commun de l'Europe, 3 REVUE DE LA COMMON LAW EN FRANÇAIS 99 (1999). Some scholars, however, have drawn an explicit connection between the scholarship that focuses on the "Europeanization" of law and the possibility of a "European law school": see, e.g., Ugo Mattei \& Mauro Bussani, The Common Core Approach to European Private Law, 3 Columbia Journal of EUROPEAN LAW, (Colum. J. EUR. L.) 339, 341 (1996); Aalt-Willem Herringa, Towards a European Law School! A Proposal for a Competitive, Diversified Model of Transnational Co-operation, in TOWARDS A EUROPEAN IUS COMMUNE IN LEGAL EDUCATION AND RESEARCH 3-13 (Michael Faure, Jan Smits \& Hildegard Schneider eds., 2002),

${ }^{14}$ See, e.g., Smits (note 11), 5-6; see also, on the "ius commune of family law" - focusing on Canon law rather than on Roman law - Masha Antokolskaia, The "Better Law Approach" and the Harmonization of Family Law, in PERSPECTIVES FOR THE UNIFICATION AND HARMONISATION OF FAMILY LAW IN EUROPE 159, 169-172 (Katharina Boele-Woelki ed., 2003).

${ }^{15}$ H. Patrick Glenn, On Common Laws 16 (2007).
} 
of communication about law, a common mentality, mainly brought about by a common culture of legal scholarship - and legal education. ${ }^{16}$ How is it possible that, in spite of this historical insight about lost unity, European (private) law discourse emphasizes the harmonization of positive law, and seems to forget about fostering a truly European culture of legal education, in the spirit of the medieval schoolmen who moved freely between places of learning all over Europe? ${ }^{17}$

Yet this lack of pedagogical discourse is not as surprising as one might, at first glance, think: European law professors have traditionally defined themselves almost exclusively through their scholarship, not through their teaching. Reflection on legal pedagogies is not, and has never been, widely accepted as proper scholarship. ${ }^{18}$ Furthermore, one always has to keep in mind that neither England ${ }^{19}$ nor the Continent ${ }^{20}$ has been exposed to a "realist" ideology as influential as the "realist" iconoclasm in the US, which sparked the tendency to critically re-assess not only the methods of legal scholarship, but also of legal pedagogy. ${ }^{21}$ The consequences are far-reaching: in Europe, the "paradigm" of legal scholarship never completely shifted away from that of $19^{\text {th }}$ century "legal science". This "paradigm" implies that what makes a great scholar is the mastery of law as a "system", and a command of the body of doctrine that surrounds the primary "sources of law". But the law-as-science paradigm also implies that judges and lawyers should employ the "scientific" approach in their work as well, and that students, too, should be brought up in its spirit. The positivist

\footnotetext{
${ }^{16}$ For a first introduction see, e.g., Peter Stein, Roman LaW In European History 71-101 (1999). On the debate on the importance of the historical ius commune for the advent of the "new" ius commune europaeum see R.C. VAN CAENEGEM, EUROPEAN LAW IN THE PAST AND THE FUTURE: UNITY AND DIVERSITY OVER TWO MILLENNIA 22-37 (2002); Reinhard Zimmermann, Roman and comparative law: The European perspective (some remarks apropos a recent controversy), 16 JOURNAL OF LEGAL HISTORY (J. LEGAL HIST.) 21, 25 (1995); Klaus Luig, The history of Roman private law and the unification of European law, 5 ZEITSCHRIFT FÜR EUROPÄISCHES PRIVATRECHT, (ZEUP) 405 (1997); Reinhard Zimmermann, Harmonisation of Private Law in Europe, in Hartkamp \& Hesselink et. al (note 11), 21.

${ }^{17}$ See also Bénédicte Fauvarque-Cosson, The RiSE of comparative LAW: A CHALlenge For Legal education IN EuRope, Walter van Gerven Lectures (7) 1-25 (2007); Ewoud Hondius, The European Private Law Movement and the changes it requires in legal education and research, in Faure et al (note 13), 39-55, calling for a "fundamental shift" in legal education (id., 55).

${ }^{18}$ Which is, of course, not to say that such scholarship does not exist: see, e.g., Stephan Leibfried, Christoph Möllers, Christoph Schmid \& Peer Zumbansen, Redefining the Traditional Pillars of German Legal Studies and Setting the Stage for Contemporary Interdisciplinary Research, 7 GERMAN LAW JOURNAL (GL) 661 (2006); see also the recent essay collection JuRISTENAUSBILDUNG IN EUROPA zWISCHEN TRADITION UND ReForm (Thomas Finkenauer, Christian Baldus \&Thomas Rüfner eds., 2008).

${ }^{19}$ See Neil Duxbury, English Jurisprudence between Austin and Hart, 91 VIRGINIA LAW REVIEW 54 (2005).

${ }^{20}$ See Kristoffel Grechenig and Martin Gelter, The Transatlantic Divergence in Legal Thought: American Law and Economics vs. German Doctrinalism, 31 HASTINGS INTERNATIONAL AND COMPARATIVE LAW REVIEW, 295 (2008).

${ }^{21}$ See, e.g., Jerome Frank, Why not a Clinical Lawyer-School?, 81 University of PenNSylvania LaW ReVIeW, (U. PA. L. REV.) 907 (1933); Jerome Frank, What Constitutes A Good Legal Education?, 19 AMERICAN BAR Association JournaL, (A.B.A.J.) 723 (1933).
} 
mindset gravitates naturally towards the law that is actually in force, and, consequently, to a strong focus on jurisdictional boundaries. This is not conducive to a way of thinking about law as transcending the nation state.

As a result, efforts at "Europeanization" of legal education have so far mostly taken the shape of programmes that consecutively expose students to national legal studies in different member states. The well-known Erasmus programme seeks to assist students of many disciplines to study in other community countries. Additionally, an increasing number of joint programmes exist in Europe where students are expected to spend an appreciable period of time studying another legal system abroad. ${ }^{22}$ The more ambitious of these programmes expect students to develop a sound understanding of the law in both jurisdictions of study; after years of study in two different jurisdictions, they bestow double degrees on their graduates. ${ }^{23}$ This approach is more consciously focused on the mastery of more than one system. However, it does not necessarily provide an integrated framework from which students could develop a synergetic understanding of law; that is to say, it may not go beyond merely adding knowledge about another "legal system" to what one has learned in one's home jurisdiction. The third and most ambitious approach has so far been adopted by the Faculty of Law of the University of Maastricht in the European Law Studies programme. ${ }^{24}$ In this programme, students having finished a first year of Dutch law enter a three year course of studies focused upon the general principles of law common to the Member States of the EC. ${ }^{25}$

However, these undoubtedly laudable initiatives affect only a small percentage of European law students, most of whom are still taught as though only one legal system

\footnotetext{
${ }^{22}$ Xavier Blanc-Jouvan, Bijuralism in Legal Education: A French View 52 J. LEGAL EdUC., 61 (2002).

${ }^{23}$ See, e.g., on double degree programmes Anne Klebes-Pelissier, Double degrees in the context of the Bologna process, 4 European Journal of Legal Education (Eur. J. Leg. Educ.), 173 (2007); Audrey Guinchard, The double degree experience between England and France: a contribution to an integrated European legal education, 4 EUR. J. LEG. EDUC. 3 (2007). Examples would be the well-established partnership between universities of Cologne and Paris I, available at: http://www.mastercologneparis.info/, or the cooperation between the universities of Groningen, Bremen, and Oldenburg, available at: http://www.hanse-law-school.de/about_hls.htm. It is worth mentioning that several European law schools are also involved in innovative global initiatives such as the Center for Transnational Legal Studies, founded under the aegis of Georgetown Law available at: http://ctls.georgetown.edu/, or the ATLAS programme ("Association of Transnational Law Schools", available at: www.atlasdoctorate.com), which is geared towards graduate students.

24 Maastricht University, Available at: www.unimaas.nl/default.asp?template=werkveld.htm\&id=TQTGGH3 RV45E65RJGTRQ\&taal=en.

${ }^{25}$ Another experiment in educating law students in several legal systems is the Hanse Law School Programme, see, (note 23).
} 
existed, by professors who know only one legal system. ${ }^{26}$ William Twining, professor at University College in London, commented on this state of affairs in 2001:

"I suspect that professional qualifications and other requirements for initial certification will continue to act as both a barrier to and barometer of the extent of transnationalisation of primary legal education and training. And until university law teachers take the idea of life-long learning seriously and act on it, our law schools, especially in the common law world, are likely to continue to be like parochial primary schools."27

One might add that, despite the fact that common lawyers tend to believe legal education in the Continental civil law jurisdictions to be more of an academic and less of a vocational training, the situation there - still - is by no means different.

\section{The "Bologna-Process"}

In recent years, the most radical agent of change that might ultimately affect many more students is the so-called "Bologna process". This process is supposed to create the "European higher education area" by making academic degree standards and quality assurance standards more comparable and compatible throughout Europe. ${ }^{28}$ The Bologna process affects, first of all, the institutional structures of legal education by calling for a reorganization of legal studies within the framework of Bachelor and Master degrees. This structural re-organization impacts the traditional methods of evaluation and affects the curriculum as well. ${ }^{29}$ One might expect that these changes to institutional structures would

\footnotetext{
${ }^{26}$ See the resolution of the "European Law Faculties Association" on Strengthening the European Dimension of Legal Education, 4 EUR. J. LEG. EDUC., 115 (2007), which is quite telling as to the current state of affairs:
}

“ELFA-Resolution II/06: European Law Teachers

ELFA encourages a European dimension of legal teaching that presupposes an educational experience abroad as a desirable feature of the career of a law teacher. The same should also be true for the judiciary. Law schools should be encouraged to require for newly appointed law teachers to have studied law abroad for at least one semester. Studies abroad have become possible by means of the Socrates-Erasmus Programme. To require such an experience for law teachers appears as a logical consequence.

Yes 55; No: 2; Abstentions: 3".

${ }^{27}$ See Twining, (note 9), 25.

${ }^{28}$ On the "Bologna process" and the EHEA in general see Laurel S. Terry, The Bologna Process and its Impact in Europe: It's so much more than degree changes, 41 VANDERBILT JOURNAL OF TRANSNATIONAL LAW, (VAND. J. TRANSNAT'L L.) 107 (2008); Laurel S. Terry, The Bologna Process and its Implications for U.S. Legal Education, 57 J. LEGAL EdUC., 237 (2007).

${ }^{29}$ Frans J. Vanistendael, BA-AIA Reform, Access to the Legal Profession, and Competition in Europe, 21 PENN ST. INT'L L. REV. 9 (2002); Frans J. Vanistendael, Blitz Survey of the Challenges for Legal Education in Europe, 18 DiCKINSON JOURNAL OF INTERNATIONAL LAW, (DICK. J. INT'L L.) 457 (2000); Frans J. Vanistendael, Curricular Changes in 
inspire a process of re-thinking the goals of national legal education in the European context. Such a development would reflect the spirit of the Bologna process, whose ten "Action Lines" not only call for the promotion of mobility and the compatibility of degrees, but also for the promotion of the "European dimension" in higher education. ${ }^{30}$

Within the context of legal studies, the promotion of the "European dimension" can be taken to imply an even stronger emphasis on the law of the EC and the EU in the curriculum. It could also mean much more. EU-related content is, of course, already the subject of intense study in European law faculties. EU-related law is, however, mostly studied as another body of positive law of another - in this case "supranational" jurisdiction. Taken seriously, the promotion of the "European dimension" calls not only for the addition of more EU-related content to an already content-laden curriculum; it also calls for a paradigm shift away from the study of law as the study of a "system" of positive law of a certain jurisdiction, and towards a de-contextualized, maybe more abstract study of legal questions that reach beyond jurisdictional boundaries.

In many jurisdictions, the effects of the Bologna process on national legal education, even so far as they only pertain to formal organization and methods of evaluation, have been perceived as changes for the worse. Particularly in Germany, where the academic study of law does not lead to university degrees but to the (in)famous "State Examination" - an extremely intense examination administered by the provincial ministries of justice resistance has been fierce. ${ }^{31}$ The major concern voiced in the German debate is that a structural re-organization will undermine the institution of the "State Examination" and, therefore, will inevitably lead to a decrease in "quality" among German graduates. The "quality" fostered by the "State Examination" is, however, modeled on the paradigm of doctrinal mastery of positive law. ${ }^{32}$ Not only practitioners, but also academics have warned against the possibly detrimental consequences of giving up the "State Examination". Only a few scholars, such as famous comparatist Hein Kötz, have openly declared that the Bologna process could be seen as an opportunity: an opportunity to transcend the fixation on positive national law. ${ }^{33}$ Kötz is well-known in the Anglophone world for his and Zweigert's treatise on comparative law, which is often derided as representing

Europe Law Schools, 22 PENN ST. INT'L L. REV, 455 (2004); and Frans J. Vanistendael, Quality Control of Students and Barriers to Access in West-European Legal Education, 43 SoutH TEXAS LAW REVIEW, (S. TeX. L. ReV.) 691 (2002).

${ }^{30}$ See, e.g., available at: http://www.europeunit.ac.uk/bologna_process/10_bologna_process_action_lines.cfm.

${ }^{31}$ See, for an English summary of the debate in Germany Laurel S. Terry, Living with the Bologna Process: Recommendations to the German Legal Education Community from a U.S. Perspective, 7 GERMAN LAW JOURNAL, 863 (2006).

${ }^{32}$ Leibfried et al., (note 18), 678; see also Helge Dedek, Recht an der Universität: "Wissenschaftlichkeit" der Juristenausbildung in Nordamerika, 64 JURISTENZEITUNG, 540, 541 (2009).

${ }^{33}$ Hein Kötz, Kurzbeitrag: Bologna als Chance, 61 JURISTENZEITUNG, 397 (2006). 
conservative "functionalism"; ${ }^{34}$ nevertheless, according to German standards, he rather seems a rebel. He has long criticized the German system of legal education that fosters a culture of positivism, most visibly embodied in the "State Examination", and has even suggested that this system fails a whole generation of students who are not duly prepared for the expectations of a globalized legal world. ${ }^{35}$ The answer to this modern challenge could be, according to Kötz, a legal education that teaches comparatively and avoids the "branding" of lawyers by national positivism. ${ }^{36}$ But, of course, the question is: can it be done? What would such a programme look like, and would it be viable in practice?

\section{An Experiment: "Trans-systemic" Legal Education at McGill}

As a contribution to this debate on the challenges posed to the teaching of law we would like to offer the following brief analysis of the efforts made at the Faculty of Law of McGill University, situated in Québec, Canada to develop a new approach to the teaching of law. Founded in 1848, the Faculty of Law of McGill University has always been characterized by a strong tradition of teaching and scholarship in comparative law. In 1968 the Faculty established a four year National Programme, subsequently amended in 1985. Ten years ago, in 1998, the Faculty undertook the effort to elevate this pedagogical project to a higher plane and to offer an integrated comparative three year curriculum, known as the McGill Programme, that teaches even first year introductory courses, such as Contracts and Torts, from a comparative perspective. The ultimate aspiration of this programme, however, is to transcend the fixation on the study of law as the study of "legal systems" hence the label "trans-systemic" legal education. In this article, we will try to outline the background and major goals of this programme, and attempt to take stock, ten years after the inception of the programme.

Reactions of observers, so far, have been mixed: in the United States, the new sensitivity for the challenge of globalization has created a certain interest in McGill's initiative. Most reactions have been positive; Professor Strauss of Columbia University even went so far as to ask whether the introduction of the McGill Programme marks the advent of a "New Langdellian Moment". ${ }^{37}$ It is an indicator of the general willingness to open up to the international aspects of legal education in the USA that more schools now find a place for comparative and international law courses in their regular curricula. More than a century

\footnotetext{
${ }^{34}$ Pierre Legrand, Paradoxically: Derrida, For a Comparative Legal Studies, 27 CARdozo LAW ReVIEW (CARdozo L. REV.) 631, 632 (2005); Ralf Michaels, The Functional Method of Comparative Law, in THE OXFORD HANDBOOK OF Comparative LAW, 340 (Mathias Reimann \& Reinhard Zimmermann eds., 2006).

${ }^{35}$ Hein Kötz, Europäische Juristenausbildung, 1 ZEUP, 268 (1993).

${ }^{36}$ Hein KÖtZ AND KonRAd ZWEIGERT, AN INTROduction to Comparative LAW 3RD Ed., $21-24$ (Tony Weir trans., 1998).

${ }^{37}$ Peter L. Strauss, Transsystemia - Are We Approaching a New Langdellian Moment? Is McGill Leading the Way?, 56 J. LEGAL EDUC. 161 (2006).
} 
after Langdell, Harvard Law School (HLS) has been leading the American charge towards a new internationalism: in 2006, HLS changed its "Langdellian" first year curriculum and added mandatory courses with international implications to the classic first year canon in order to prepare students, as Dean Kagan put it, for the "new complex global challenges of this millennium". Each student now has to take one of three courses "introducing global legal systems and concerns - Public International Law, International Economic Law, [or] Comparative Law". ${ }^{38}$

Reactions from Europeans have been more cautious. ${ }^{39}$ McGill hosted two conferences ("Roundtables"), gathering American and European scholars to discuss the workability of "trans-systemic" legal education in different contexts, and particularly to highlight the connection between substantial rapprochement, which is at the heart of so many European projects at the moment, and a change of "legal culture" that is unthinkable without changing the culture of legal education. Opinions voiced at these occasions seem to indicate one main objection: a "trans-systemic" approach is viable only in the particular environment of a mixed jurisdiction. Only in this particular environment, goes the argument, might it be the case that teaching students a comparative approach to law will help to achieve the primary goal of legal education: providing students with a sufficient understanding of their domestic legal system.

Given the persistent predominance of the positivist paradigm of legal education in Europe, these reactions are not surprising. We want to argue, however, that to perceive the "transsystemic" project as simply another oddity to be encountered in a mixed jurisdiction would be a misunderstanding. To be sure, the programme has, as its history underlines, grown out of the particular condition of mixedness in Québec. Nevertheless, at its core lies an ambition that is not tied to the specific idiosyncrasies of the mix of common and civil law in Québec. This ambition is, in short, to bring about an approach to legal education that liberates it from its ties to a positivistic training in the law in force in a certain jurisdiction. It is rather, as it has been pointed out, "an opportunity to locate law more resolutely in the university, not as a matter of geography, but of ideas, and to situate it there as an example of what might be called a foundational discipline." ${ }^{\prime 0}$ Its aspiration is to eventually

\footnotetext{
${ }^{38}$ Available at: http://www.law.harvard.edu/news/2006/10/06_curriculum.php.

${ }^{39}$ With the notable exception of Paul Maharg, who, reporting on developments in North American legal education, groups together curriculum reforms at Harvard, Stanford and McGill and calls McGill's innovation "perhaps one of the most radical". He commends all these reformative efforts, pointing out that the "key to their innovation is a profound re-alignment of curriculum structure and methodology, from the most theoretical aspects to the most practical" (Maharg, (note 2), 98).

${ }^{40}$ Nicholas Kasirer, Bijuralism in Law's Empire and Law's Cosmos, $52 \mathrm{~J}$. LEGAL EDUC., 29, 30 (2002). On the broader intellectual project and philosophical imagination behind the curriculum change see also Richard Janda, Toward Cosmopolitan Law, 50 McGILL LAW JournaL, (McGILL L.J.) 967 (2005); Roderick A. Macdonald and Jason MacLean, No Toilets in Park, 50 McGiLL L.J., 721 (2005).
} 
overcome the traditional Western bias of conceptualizing law as nothing but a "system" that is enacted by a state, and to free the educational discourse about law from its positivistic constraints. ${ }^{41}$ In that sense, the programme is not tied to Québec as a mixed jurisdiction, given that its ambition goes far beyond the teaching of the mixed law of Québec. More important is the intellectual climate that forms the condition of possibility for such a project. Without a doubt, the mindset prevalent in a mixed jurisdiction, the experience of being mixed, interstitial and in flux, is particularly conducive to an experiment such as McGill's. ${ }^{42}$ Eventually, however, the conditio sine qua non for its existence is a mindset, such as the particular North American tendency towards a less positivistic and more intellectual legal education: a culture rather than a place.

\section{B. Historical Background: Legal Education in a Mixed Jurisdiction}

\section{Mixité: Civil and Common Law in Québec}

It is true, however, that the origins of the "trans-systemic" programme are to be found in the ambition to accommodate the particular challenges posed by Canadian bijuralism. ${ }^{43}$ Canada is a federal country where two systems of private law, a civil law system in Québec and one or several common law systems outside Québec, have coexisted since the late 18th century. ${ }^{44}$ After their victory over France, the British attempted to "anglicize" the colony of New France that was now called "Québec". This included an attempt to introduce English law. It was an ill-conceived attempt, soon to be abandoned. British pragmatism knew better than to provoke unnecessary frictions, and with the promulgation

\footnotetext{
${ }^{41}$ H. Patrick Glenn, Doin' the Transsystemic, 50 McGILL L.J. 863 (2005). It is important to note that, despite the connection frequently made between the ambit of the programme and the process of "globalization", "law", which is still the object of study of the programme, is not just another, now "global" legal system or "world law" brought about by a process of "harmonization" or "convergence". The programme attempts to understand global legal diversity as a cultural plurality by, for example, using the heuristic tool of the "tradition", as most notably suggested by H. Patrick Glenn. Conceptualizing "law" as "tradition" allows, according to Glenn, for a "normative engagement" with otherness (as opposed to the hierarchic dominance of the positivist, "systemic" approach), while explaining, at the same time, the necessity to sustain diversity. See H. Patrick Glenn, A Concept of Legal

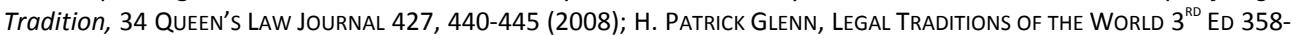
365 (2007).

42 Nicholas Kasirer, Legal Education as Métissage, 78 Tulane Law ReVIeW, (TUL. L. ReV.) 481 (2003).

${ }^{43}$ In this context, it is interesting to contrast the approach of the McGill programme, which attempts to connect the experience of mixedness with a globalized "mindset", with another innovative Canadian attempt to rise to the "global challenge": cf. Craig Scott, A Core Curriculum for the Transnational Legal Education of JD and LLB students: Surveying the Approach of the International, Comparative and Transnational Law Program at Osgoode Hall Law School, 23 PENN ST. INT'L L. REV., 757 (2004-2005).

${ }^{44}$ For a succinct but scholarly and well-documented overview of the origins and modern implications of this reality, see Part One of JoHn E.C. BRIERLEY AND Roderick .A. MACDONALD, EDS., QUeBEC CIVIL LAW - AN INTROdUCTION TO QueBec PRIVATE LAW, 5-198 (1993).
} 
of the so-called Québec Act of 1774, the British guaranteed freedoms important to the "French" identity of the populace. That private disputes would continue to be adjudicated according to the rules of French civil law - meaning, at this point, according to the Coutume de Paris - was one of these guarantees. The fact that law figures so prominently next to religion underlines that even "legal culture" can be the focal point of a group identity. Thus, the ingredients of the mixture were defined: French civil law within the framework of English public law and laws of procedure.

In addition to the Coutume de Paris, Québec private law has its historic origins in the original $1865^{45}$ and the contemporary 1991 Civil Code, in its provincial statutes and in federal private law. With its predominantly French heritage, the private law of Québec has however benefited from many English contributions, particularly in the field of commercial law. Particularly the city of Montreal developed, after the defection of the USA, into the Empire's most important bridgehead for English trade in the New World. ${ }^{46}$ Former Dean Morissette explains the relationship between the civil and the common law influences in Québec private law as follows:

"[T]here are large swaths of private law proper (divorce, for example), as well as commercial and business law (business associations, banking and bills of exchange, bankruptcy, intellectual property, securities, etc.), or procedural and adjectival law (the structure of the courts, the adversarial system and civil procedure, statutory interpretation), where the common law tradition dominates or occupies the field through and through, or where law has become asystemic." ${ }^{47}$

Moreover, many of Québec's legislative, judicial, executive and administrative institutions and processes belong to the English public law tradition, hence the singular situation of a body of civil law evolving within a common law institutional structure. ${ }^{48}$ The manner of reporting judicial decisions in Québec is inconsistent with the civil law theory that there

\footnotetext{
${ }^{45}$ See John E.C Brierley, Quebec's Civil Law Codification Viewed and Reviewed, 14 MCGILL L. J., 523 (1968).

${ }^{46}$ See also Stanley B. Frost, The Early Days of Law Teaching at McGill, 9 DalhousIE LAW JouRnAL (DALhousie L.J.) 150 (1984).

${ }^{47}$ Yves-Marie Morissette, McGill's Integrated Civil and Common Law Programme, 52 J. LEGAL Educ. 12, 15 (2002). Morissette also notes that the particular configuration of this mixity explains why certain commentators have raised questions about the density of the civil law tradition still present in Canada, citing Catherine Valcke, Legal Education in a 'Mixed Jurisdiction': The Quebec Experience, 10 TULANE EUROPEAN AND CIVIL LAW ForUM, (TUL. EUR. \& CIV. L.F.) 61 (1995); Catherine Valcke, Quebec Civil Law and Canadian Federalism, 21 YALE JOURNAL OF INTERNATIONAL LAW, (YALE J. INT'L L.) 67 (1996); and Peter Stein, Roman Law, Common Law and Civil Law, 61 TUL. L. Rev., 1591, 1602 (1992).

${ }^{48}$ John E.C. Brierley, Bijuralism in Canada in CONTEMPORARY LAW: CANAdIAN RePORTS to THE 1990 InTERnAtional Congress of Comparative LaW, Montreal 1990 (H.P. Glenn ed., 1992).
} 
can only be one answer to a legal question; not only do judges give individual opinions, but frequently dissenting ones, too. "Although stare decisis is not part of Québec law, court decisions are given very considerable weight in judicial analysis., ${ }^{50}$

\section{Legal Education in a Bijuridical and Bilingual Jurisdiction}

In a mixed jurisdiction such as Québec, legal education takes on a particular importance. To some degree, all students must possess both the civil law tools necessary to analyze a private law problem, and the common law training to apply Canadian public law. In the words of Catherine Valcke:

"[L]egal players must be capable of playing two games at once, which requires that they be trained to juggle with, and yet never confuse, two distinct set of rules. Only if legal players can properly accomplish this will the integrity of the various games being played be preserved. In mixed jurisdictions, therefore, it is the very identity of the legal games, not just their respective dynamism, that is at stake for legal education. ${ }^{51}$

Québec therefore presented itself as an intellectual breeding ground for exploring the plural character of law, using the methodology of comparison. And McGill has, from the outset, played its part in this story - again, in the words of Dean Morissette:

"[I]t bears repetition that McGill's Law Faculty, from its earliest days, perhaps because of the proximity of a vastly influential other legal tradition, has always been habited by the conviction that a great deal can be gained in legal scholarship from a sustained and humble dialogue with otherness. $^{\prime 52}$

\section{Law Teaching at McGill: From the Beginnings to the National Programme}

This "humble dialogue" was, at first, born out of sheer necessity. The reaffirmation of the Coutume de Paris by the Quebec Act of 1774 had caused a state of legal confusion in the minds of the Montreal English merchant class; in 1787, James McGill himself testified in the Court of Common Pleas that he had never heard any complaints touching the

\footnotetext{
49 Julie Bédard, Transsystemic Teaching of Law at McGill: 'Radical Changes, Old and New Hats', 27 QUEEN's L.J., 237, 246 (2001).

${ }^{50}$ Id. Bédard comments that the situation has changed and that the Supreme Court no longer considers itself bound by its own decisions, whether they involve civil law or common law matters.

${ }^{51}$ See Valcke, (note 47), 62.

${ }^{52}$ Morissette (note 47), 22.
} 
administration of justice until the re-affirmation ${ }^{53}$ of the Coutume de Paris, but that "since that period, they have been loud and frequent, and in my humble opinion have arisen from the Anarchy and confusion which prevail in the laws and the Courts of Justice in the province. ${ }^{54}$ Looking for guidance through education, requests to McGill College were made, particularly by the Montreal Anglophone community, to offer courses in law; in 1848, University records first mention the "Law Class of McGill College". ${ }^{55}$

In a speech held in 1859, M. Desiré Girouard, later a Supreme Court justice, still decried the state of confusion that resulted from the multitude of legal sources, and from having to consult French, Roman, English, American and Canadian authorities in every judicial decision. ${ }^{56}$ In this hotchpotch of real-life everyday legal plurality, the Faculty of Law of McGill University was a pioneer in recognizing and developing the potential for teaching law comparatively. In the mid-nineteenth century, at a time when Montreal was considered Canada's financial and industrial centre of gravity, the Faculty had to face a particular reality. ${ }^{57}$ As the only English-speaking law school in Québec, "many of its graduates would practice law, and notably commercial law, across systemic boundaries, and they needed some exposure to private common law. ${ }^{\prime 58}$ More significant, however, was the appointment of two successive deans who brought to the Faculty a high degree of commitment to the scholarly study of law. ${ }^{59}$ Under their influence, the major elements of McGill's first polyjural, universalist and bilingual curriculum were put into place, reflecting the dual origins of Canadian law. ${ }^{60}$ During the decade of the 1920 's, common law courses

\footnotetext{
${ }^{53}$ Andre Morel, La Reaction des Canadiens devant l'administration de la justice de 1764 a 1774: une forme de resistance passive 20 LA REVUE DU BARREAU DE LA PROVINCE DE QUEBEC 53 (1960). As to the "uncertain status of civil law" in the years immediately preceding the Quebec Act of 1774 , see, also, Brierley \& Macdonald, (note 44), 1416.

${ }^{54}$ Stanley B. Frost, The Early Days of Law Teaching at McGill, 9 DALHousIE L.J., 150, 151. (1984).

${ }^{55}$ Id., 153.

${ }^{56}$ Cited to Edouard-Farbre Surveyer, Une école de droit a Montréal avant le Code Civil, 6 ReVUe TRIMESTRIelle CANADIENNE, 142 (1920). It should be noted that recourse to a multitude of legal sources was not unique to the courts of Québec but was also common in the common law colonies until well into the Nineteenth Century, see, e.g., Oliver Mowat, Observations on the Use and Value of American Reports in Reference to Canadian Jurisprudence, 3 UPPER CANADA LAW JOURNAL, 8 (1857).

${ }^{57}$ Morissette (note 47), 4.

${ }^{58} I d$.

${ }^{59}$ Frederick Parker Walton, appointed Dean in 1897, was a Scottish civilian and romanist from Glasgow, while Robert Warden Lee, appointed Dean in 1915, was an English romanist from Oxford. Another influential addition to the Faculty was Herbert Arthur Smith, trained in Oxford, who had spent a number of years in the United States, and who was recruited by the Faculty in 1920 as Professor of Jurisprudence and Common Law.

${ }^{60}$ For a thorough account of this period in the Faculty's history, see. Roderick A. Macdonald, The National Law Programme at McGill: Origins, Establishment, Prospects 13 DALHOUSIE L.J., 211, 243-260 (1990). See also John E.C. Brierley, Developments in Legal Education at McGill, 1970-1980, 7 DALHOUSIE L. J., 364. (1982).
} 
were offered alongside the regular civil law program. However, it took another fifty years before a "National Programme" was formally offered to incoming students. ${ }^{61}$

The philosophy of this National Programme, first adopted in 1968, was fairly straightforward. It was based upon the conviction that knowledge of both Canadian legal traditions was an asset, intellectually and professionally. ${ }^{62}$ In the broadest sense, it could be seen as contributing "to the promotion of mutual understanding between different regions of the country." ${ }^{\prime 3}$ By providing students with training that allowed them to qualify as lawyers in both civil law and common law jurisdictions, the National Programme not only increased professional mobility in the country but also began to produce jurists who could more easily find work in transnational and international environments. Indeed, double degree graduates were fully qualified to practice law across Canada, and were increasingly qualified for practice in a number of American and other jurisdictions. Moreover, as one professor pointed out, "it is noticeable that students proceeding to graduate work, at McGill and elsewhere, are more often than not those with the full dual training." ${ }^{64}$

During the first thirty years of its existence, the National Programme offered three possibilities to students entering law school: (i) completing a civil law degree in three years and in 95 credits, or (ii) completing a common law degree in three years and in 95 credits, or (iii) completing both degrees in four years and in 125 credits. The approach adopted in the early years of the programme was sequential. Rather than integrating the teaching of both legal traditions, the programme juxtaposed them in such a manner that students entering law faculty were branded as belonging to one or the other of the two traditions. As such, those in the civil law stream completed their basic private law courses in civil law in Year I; and in Year II, or over the course of the following three years, they had to complete the corresponding basic private law courses in common law. ${ }^{65}$

\footnotetext{
${ }^{61}$ As early as in 1919, Dean Robert Warden Lee made efforts to give legal education at McGill a new direction and push it beyond a training for the admission to the local bar, integrating pan-Canadian and international elements into an academic course of study. In an intellectual climate that was not quite ready to embrace such a noninsturmental view of legal education, Lee met strong resistance from the local bar. See MacDonald (note 60), 253254. It is interesting to note the "interdisciplinary" thrust of Lee's ambitions, promoting the study of legal history and Roman law; see, e.g., Robert W. Lee, The Place of Roman Law in Legal Education, 1 CANAdIAN BAR Review, 132 (1923).

${ }^{62}$ Brierley (note 60)., 365.

${ }^{63} / d$.

${ }^{64} I d ., 369$.

${ }^{65}$ For a detailed discussion of the National Programme from 1968-1998 see id.; Macdonald, (note 60).
} 
Over time, it became apparent that students who had at least one year of exposure to the study of law would not learn the basics of the other tradition in the same manner as their first-year counterparts and that, therefore, they should be taught differently. From 1985 to 1999, a second pedagogical approach emerged with the development of "cross-over" courses designed specifically for students having completed their basic training in one tradition.

"[S]econd-year courses were taught in an explicitly comparative basis, drawing insight from the student's prior exposure to the same ideas in their first year. In the third and fourth year of the program, students would have various options to take courses in the civil law or common law tradition, in order to graduate with both degrees." ${ }^{\prime 66}$

Despite the Faculty's effort to develop the comparative law potential of the National Programme, bijuralism continued to be understood as the cohabitation of two largely autonomous orders of private law and any comparative endeavour remained, for the most part, secondary. In the words of one professor: "[b]ijuralism at McGill [...] meant peaceful cohabitation rather than active dialogue between the common law and the civil law." ${ }^{67}$

\section{Beyond Jurisdictional Boundaries: The McGill Programme}

\section{Merging the two branches of the National Programme}

Three decades after the institutionalization of the National Programme came the third major reform of the curriculum. The 1998 reform, known as the McGill Programme, was a response to a number of external and internal pressures. These included the desire to make the Faculty more attractive to a wider array of students and the perceived need to locate the teaching of law "more resolutely in the university, not as a matter of geography but of ideas [...] as an example of what might be called a foundational discipline." ${ }^{\prime 68}$ The new curriculum developed as the logical extension of its predecessor, diverging from the National Programme largely in degree rather than in kind. In fact, as one professor recently noted, "the history of McGill's law curriculum after 1968 is one of progressive and ever increasing integration of the civil and the common law traditions, from juxtaposition to partial amalgamation where subjects permit it." ${ }^{\prime 69}$ Under the new program, implemented in

\footnotetext{
${ }^{66}$ Daniel Jutras, Two Arguments for Cross-Cultural Legal Education, in GRUNDLAGEN UND SCHWERPUNKTE DES Privatrechts in eURopäISCher Perspektive, vol. 3, 75 (H.D. Assmann, G. Brüggemeier \& R. Sethe, eds., 2001).

${ }^{67}$ See Kasirer, (note 40), 29.

${ }^{68}$ Id., 3.

${ }^{69}$ Morissette (note 47), 6.
} 
1999, streaming has been abandoned. All students are admitted into a single integrated program, and all graduate with both degrees. Basic private law courses are no longer taught in function of a single legal system but in function of overarching categories of law such as contracts and civil responsibility. ${ }^{70}$

The cornerstone of the reform has been the advent of trans-systemic courses in which an area of law is treated as a unified field across the divide of different legal traditions. Some of the "core" courses that currently that are taught trans-systemically are: "Extracontractual obligations / Torts", "Contractual Obligations / Contracts", "Business Associations", "Comparative Federalism", "Family Law", "Evidence (Civil Matters)", "Private International Law", "Secured Transactions" and "Sale". In first year, Civil Law Property is the one private law course that is not taught trans-systemically because of its systemic development and its cultural specificity, and in order to give students an opportunity to experience the internal "logic" of either system.

By integrating what used to be two courses into one, trans-systemic teaching is designed to promote a more profound and coherent understanding of fundamental legal principles, rather than to simply teach the logic of a single system of law. Considerations of space do not permit to elaborate in great detail on the pedagogical challenges that come with the attempt to teach "trans-systemically". ${ }^{71}$ Suffice it to say that one of the major challenges the teacher faces in the "trans-systemic" classroom is to resist the temptation to simply juxtapose legal "solutions", but to develop a synthesis of the different approaches capable of conveying a synergetic surplus that justifies the integrated format. Moreover, the omnipresent experience of difference leads almost naturally to the attempt to explain discrepant and distinct developments in the respective legal traditions, which, from early on, connects legal discourse with the discussions of historical, sociological, economic, philosophical etc. questions in the classroom - another aspect that makes teaching in the trans-systemic format an exciting, but also difficult task.

This integrated approach has the practical effect of permitting a reduction of the number of credits required to graduate with both degrees, from 125 to 105 . Students are thus able to complete their studies in three (very heavy) years of study rather than the four years required until 1998. That said, some students still choose instead to pursue their studies for a further term or even another full year in order to participate in exchange programmes, to pursue further research work or even simply to proceed towards their degree at a slower pace.

\footnotetext{
${ }^{70}$ See, e.g., Rosalie Jukier, Where Law and Pedagogy Meet in the Transsystemic Contracts Classroom, 50 McGILL L. J., 790. (2005); Rosalie Jukier, Transnationalizing the Legal Curriculum: How to Teach What We Live, 56 J. LEGAL EDUC., 172 (2006).

${ }^{71}$ For a full description see Jukier (note 59).
} 


\section{From "Law's Empire" to "Law's Cosmos"72}

The new program fits in the movement toward a more academically ambitious model of legal education. While a trans-systemic legal education is without a doubt "an open door on the world" ${ }^{73}$, its architects thought of it, first and foremost, as "an invitation to students and scholars to think of law in a new way, in terms other than those of the jurisdictional or geographical representations of law that have dominated North American legal education in the past." ${ }^{\prime 74}$

The reform of 1999 was also the occasion for an introspective debate on the skills imparted by the programme and on the particular form of jurisprudential awareness it can cultivate in students. ${ }^{75}$ With a view to developing new learning opportunities, the Faculty approved an ambitious Human Rights internship programme, Minors in other disciplines, Majors in particular fields of legal specialization and an Honours thesis. ${ }^{76}$ Again, the rationale for these innovations stemmed from a vision of law as a discipline with a firm place in the academy among the social sciences and humanities.

McGill has always been committed to a liberal education, but with the new programme, the liberal endeavour is raised a notch by challenging the temporality and territoriality of legal normativity: "[I]f the study of law can be conceived as an end in itself, as an academic discipline, as an inquiry into one dimension of culture and social organization, why should it be confined to the norms and culture of the positive law of the jurisdiction in which a given faculty happens to be located?" ${ }^{\prime 77}$ It is believed that trans-systemic teaching has a potential for sharpening, deepening and expanding the lenses through which one perceives law. ${ }^{78}$

However critical this pedagogical approach might be of the traditional "jurisdictional or geographical representations of law that have dominated North American legal education", it is obvious that it can only exist in an intellectual climate that does not reduce the scope of legal education to the study of doctrine of positive law. The transsystemic experiment is, in that sense, intellectually closely related to the tendencies in

\footnotetext{
${ }^{72}$ See Kasirer (note 40).

${ }^{73}$ Id., 31.

${ }^{74}$ Id.

${ }^{75}$ See Morissette (note 47), 21.

${ }^{76} / d$.

${ }^{77}$ See Jutras (note 66), 83.

${ }^{78}$ See Bédard (note 49), 279.
} 
American legal education to overcome the boundaries of the study of law as an exercise in doctrinal positivism. Only if it is a given that legal education should be about more than the mastery of positive rules, a programme such as McGill's can hope for acceptance. This culture of legal education is the intellectual foundation on which the programme rests; this is why European scholars, coming from an entirely different culture of legal education, must perceive the programme as the odd product of a mixed jurisdiction. Both pedagogical innovations and innovative responses to what has been called the "complex global challenges of our new milennium" are predicated on the existence of a culture of legal education that is able to re-imagine itself beyond its own traditional parochialism.

\section{For Instrumentalists: Practical Advantages}

Cui bono some readers may ask. The theory surely sounds nice. But does this approach actually help students to better understand the law? There exist, as we have seen and as, e.g., Professor Blanc-Jouvan has noted, ${ }^{79}$ excellent programmes in Europe in which students can study for two years in France and two years in England, or another EU country, thereby acquiring a solid grounding in both the civil and the common law. Why go this extra very complex mile? What is gained?

A first result of the McGill Programme is that students cease to be "branded" as common or civil lawyers and as a result can be said to have a more complex legal identity, arguably one better suited to the complexities of the world. Secondly and equally important from the pedagogical perspective, students cease to carry the sole burden of comparative analysis. They are no longer taught by professors whose perspective is unisystemic, but rather by professors who are engaged in the same complex enterprise that they have embarked upon. Thirdly, comparative analysis ceases to be an addition and becomes central to their work as law students. Finally, law teaching from a trans-sytemic perspective is much more easily aligned with the broader social sciences and the humanities; the search for general principles becomes more necessary and the study of law is less likely to be dominated by the professionalist ethic.

Broadly, the result is that students cease to think in terms of a single national legal paradigm and are instinctively prepared to cope with several jurisdictions in any given situation. Law ceases to be seen from a single national perspective. Surely this is a message that is relevant to the European Union. The true framework within which modern law is developing has ceased to be the single jurisdiction: the sources of legal rules are increasingly multinational and trans-systemic. Jurists, whether academics, judges, lawyers, legal counsel employed by governments, corporations or NGOs, must have a broader frame of reference within which to work. In this respect, the EU is the exemplar of what is happening in the broader world.

\footnotetext{
${ }^{79}$ Blanc-Jouvan (note 22).
} 
Whether they are engaged in drafting or analysis of contracts, litigation, advocacy, policymaking in government service or work for NGOs, jurists need to be sensitive to the influence of different systems. Within the EU a lawyer called upon to apply the ECT article 288 will surely benefit from training that calls for the ability to think of legal rules outside a single jurisdiction. A jurist called upon to work with a common code governing commercial contracts will understand the principles of the code far more readily if she comes at it from a perspective which is not tainted by the instinctive belief that there is only one genuine legal system - that in which they were first trained. Administrative lawyers working with the EC concept of general principles of law can do so much more readily if their judgment is not clouded by instinctive fidelity to their system of origin. Complex commercial contracts no longer can be understood in function of a single legal system, yet most law students are not taught this fact or trained to deal with it. A trans-systemic training is designed to meet this need.

\section{Critique: "Madly off in one direction"?}

After ten years of pursuing the "trans-systemic" experiment, it befits us to ask whether the programme has actually reached its goals. An answer to this question is not easy to give. One has to distinguish between the expectations of intellectual progress in legal education - a somewhat lofty goal whose very nature makes it difficult to judge one's own achievements - and the "instrumental" goal to prepare students for a transnational, globalized job market. The impact of the curriculum change on the employment opportunities of graduates of the McGill Programme is difficult to measure as well, given the lack of reliable statistics. The response of the Canadian legal profession, which had been skeptical in 1968, was much more enthusiastic in 1998. Surveys undertaken in the context of the attempt to rank Canadian law schools, involving the assessment of Canadian employers, indicate that McGill graduates are doing well on the job market; ${ }^{80}$ so do the McGill graduates clerking at the Supreme Court of Canada, whose number, during the last years, has been higher than that of any other law school graduates in Canada. As to the international success of graduates of the programme, there only exists anecdotal evidence, documenting single successful careers with American or European law firms or international organizations, but recruitment of McGill graduates by international firms is now a well-established practice. Until an actual empirical study is undertaken, it will be difficult to draw firm conclusions. However, judging from the data so far available it seems fair to say that the curriculum change has not hurt, and even appears to have enhanced the prospects of McGill graduates. The concern that the comparative approach might have been purchased at the price of a less thorough training in the positive law, thus

\footnotetext{
${ }^{80}$ In McLean's ranking of Canadian law schools, McGill comes $2^{\text {nd }}$ after the University of Toronto in the category "Elite Law Firm Hiring"; this survey, however, categorized McGill as a "common law school" and completely ignored its Civil Law Branch (available at: http://www.macleans.ca/education/universities/article.jsp? content=20070917_204046_1504\&page=2).
} 
endangering graduates' "employability" - the European positivist objection to the ideology underlying the programme - seems unfounded.

It is also hard to assess whether the programme has come up to its own intellectual expectations. As Harry Arthurs, former Dean of Osgoode Hall Law School and former President of York University, has remarked: given the complex theoretical justifications for the curriculum change, judgments about the operation of the programme are confronted with the conceptual problem that "the standard of judgment the programme has defined for itself is not how it functions at any given moment, but rather how it evolves over time" ${ }^{81}$ Indeed, to assess whether the programme has evolved even further before concluding that it "functions" in the first place seems hardly feasible. However, it can be said that the whole faculty at least is engaged in a permanent attempt to propel such an evolution: at McGill there is an ongoing process of critical self-assessment and selfreflection, documented by faculty seminars, conferences and scholarly publications on the topic of legal education. At the moment, a committee struck by the faculty is charged with a review of the achievements of the programme. Critique from the outside has been taken seriously, such as Peter Strauss's admonition to better include other emanations of the civilian tradition than French and Québec law ${ }^{82}$ - one of the considerations taken into account when it was decided to hire civil law-trained faculty from Puerto Rico and Germany.

In addition to pointing out the difficulties of realistic self-assessment, Harry Arthurs has put forward what is probably the most challenging critique in regard to the substantive focus of the programme: In its strong belief in the value of comparative law, Arthurs claimed, the McGill programme went "madly off in one direction". Its revolutionary fervor, he implies, is somewhat stuck in a "legal" perspective, while a true effort to make legal education an interdisciplinary endeavour has so far been lacking. ${ }^{83}$

The programme does already include a number of courses with an interdisciplinary ambit. Nevertheless, Arthurs's point is well taken, and the commensurability of the "transsystemic" programme and an even more trans-disciplinary approach to legal studies is a much debated question. The trans-systemic project, which is at heart a comparative project, still emphasizes "law" and the comparison between "laws" as a major focal point. From the perspective of a radical claim to anti-formalism and interdisciplinarity, Arthurs's critique must seem, to a certain degree, well-founded: relying on comparative law as a pedagogical tool shows a remaining (if unspoken) belief in the heuristic potential of an

\footnotetext{
${ }^{81}$ Harry Arthurs, Madly Off in One Direction: McGill's New Integrated, Polyjural, Transsystemic Law Programme, 50 MCGILL L.J. 707, 711 (2005).

${ }^{82}$ See Strauss (note 37), 167.

${ }^{83}$ See Arthurs (note 81), 715.
} 
approach that starts from an internal analysis of law. Indeed, the organic integration of more trans- or interdisciplinary courses in the curriculum, and, on a more general level, the adoption of a more trans-disciplinary epistemology is perceived by many as marking the necessary next stage of development for the programme.

The European observer, however, might read in disbelief that McGill's experiment is being criticized for its traditional fixation on law. Indeed, if we ask the question whether the ideology of the McGill programme could be exported to Europe, those parts of the programme that involve - from Arthurs's point of view - an overly legalistic and rather conventional comparative approach might be potentially viable in and most interesting for the European context. It might already seem counterintuitive to the European tradition of positivistic legal education to move away from the paradigm of vocational training in a certain jurisdiction. A comparative curriculum has long been on the wish list of (Continental) comparatists. ${ }^{84}$ While Europe surely is not yet ready to embrace the "interdisciplinary paradigm", a comparative, transnational approach that at least still focuses on "law" might - someday - be more acceptable.

\section{Conclusions}

What is happening at McGill is not simply a utilitarian effort to alert students to the complexities of life that await them as jurists and lawyers in the future. Much more is at stake. Once one begins to approach the teaching of law from a trans-systemic or multisystemic perspective, it is quickly apparent that what is at stake is the very nature of law. The teaching of law at McGill reflects both the coexistence of two legal cultures that meet with particular intensity in Québec and the sense that single jurisdictions no longer, if they ever did, contain within themselves a true understanding of the meaning of law. The programme is the attempt to answer the challenge of the "cosmopolitanism" of law, enabled by an intellectual climate in North America that has long left behind the positivistic paradigm of legal education.

Does this programme have any relevance for legal education in the EU? We have tried to emphasize that the philosophy of the programme reaches beyond the particular and singular condition of one single (and small) mixed jurisdiction. Moreover, European jurisdictions are "mixed" as well; the process of mixing, merging and blending is surely even more complex in the EU than in mixed jurisdictions where only two legal traditions meet. EU law has already begun to seek common principles of law, and now draws heavily upon a number of legal systems. The EU has also embarked upon the search for constitutional legal principles to govern a multi-polar and multisystemic political system. What it has yet to undertake is the development of a system of legal education adapted to

${ }^{84}$ See, e.g., Kötz \& Zweigert (note 36), 23-24; Dedek (note 32), 540, 548. 
the training of jurists for this new reality. As this process accelerates, it is important that the process be understood as one of the central features of the development of the EU, not only as a legal undertaking but also as a human and political community. It calls for a new mentality, for a true understanding of pluralism rather than the extension of the positivistic mindset to a multitude of legal orders. Europeans should remember their heritage: regain the insight that the ius commune that is so readily invoked in current discussions was a common culture rather than a common legal system; and embrace the seminal role of legal education in the formation of such culture. 
